\title{
Central tolerance: what have we learned from mice?
}

\author{
Tom M. McCaughtry $•$ Kristin A. Hogquist
}

Received: 24 July 2008 / Accepted: 1 October 2008 / Published online: 23 October 2008

(C) The Author(s) 2008. This article is published with open access at Springerlink.com

\begin{abstract}
Producing a healthy immune system capable of defending against pathogens, while avoiding autoimmunity, is dependent on thymic selection. Positive selection yields functional $\mathrm{T}$ cells that have the potential to recognize both self and foreign antigens. Therefore, negative selection exists to manage potentially self-reactive cells. Negative selection results from the induction of anergy, receptor editing, clonal diversion (agonist selection), and/or clonal deletion (apoptosis) in self-reactive clones. Clonal deletion has been inherently difficult to study because the cells of interest are undergoing apoptosis and being eliminated quickly. Furthermore, analysis of clonal deletion in humans has proved even more difficult due to availability of samples and lack of reagents. Mouse models have thus been instrumental in achieving our current understanding of central tolerance, and the evolution of elegant model systems has led to an explosion of new data to be assimilated. This review will focus on recent advances in the field of clonal deletion with respect to three aspects: the development of physiological model systems, signaling pathways that lead to apoptosis, and antigen presenting cell types involved in the induction of clonal deletion.
\end{abstract}

\section{Keywords Thymus $\cdot$ Clonal deletion $\cdot$ Tolerance}

The prevention of autoimmunity is primarily the outcome of central tolerance, which is achieved when thymocytes with high affinity for self-peptide/major histocompatibility complex (self-p/MHC) undergo negative selection. Four

T. M. McCaughtry $\cdot$ K. A. Hogquist $(\bowtie)$

Center for Immunology, Laboratory Medicine \& Pathology,

University of Minnesota,

Mayo Mail Code 334, 420 Delaware Street SE,

Minneapolis, MN 55454, USA

e-mail: hogqu001@umn.edu outcomes of negative selection have been described. First, receptor editing is a process by which thymocytes with high affinity for self-p/MHC are instructed to generate a second rearrangement of the T cell receptors (TCR) $\alpha$ loci, thereby altering the specificity of the TCR [1-4]. Secondly, anergy, or a state of induced unresponsiveness, has also been described [5]. The relative contribution of receptor editing and anergy to central tolerance is thought to be minimal. Instead, clonal diversion (agonist selection) of high-affinity thymocytes into lineages that attain immunoregulatory function is very important (reviewed in [6-9]). Finally, clonal deletion (induction of apoptosis in self-reactive clones) is the predominate mechanism by which central tolerance is achieved and will be the focus of this review.

\section{Model systems}

In 1957, Sir Macfarlane Burnet first proposed the concept of "repertoire purging" as a mechanism of lymphocyte tolerance [10]. This process was first described experimentally for thymocytes by studying clonal deletion in response to superantigens [11] (see Table 1). Superantigens are molecular remnants of proviruses in the murine genome that cross-link particular $\mathrm{V} \beta$ segments of TCRs with class II MHC. While this mimics a high-affinity TCR ligation, it is unclear if the downstream signaling events are entirely the same as stimulation by $\mathrm{p} / \mathrm{MHC}$. Soon after, in vitro stimulation of thymocytes with high-affinity ligands was utilized to model clonal deletion [12-14]. However, it is unlikely that in vitro stimulation recapitulates the in vivo process of clonal deletion because the intact thymic microenvironment is missing. The switch to in vivo models was a substantial improvement and first utilized the injection of TCR-cross-linking antibodies to simulate 
Table 1 A summary of model systems used to study negative selection

\begin{tabular}{|c|c|c|c|}
\hline Model system & Caveats & Advantages & Disadvantages \\
\hline Superantigens & $\begin{array}{l}\text { Only particular } \mathrm{V} \beta \mathrm{TCR} \\
\text { are deleted } \\
\text { Expression mostly in } \\
\text { medulla }\end{array}$ & Endogenous antigen & $\begin{array}{l}\text { TCR signal may be qualitatively or } \\
\text { quantitatively distinct }\end{array}$ \\
\hline $\begin{array}{l}\text { In vitro } \\
\alpha \mathrm{CD} 3 / \alpha \mathrm{CD} 28 \\
\text { TCR Tg peptide }\end{array}$ & Costimulation required & Technically simple & Intact thymic microenvironment lacking \\
\hline In vivo: $\alpha \mathrm{CD} 3 / \alpha \mathrm{CD} 28$ & & Intact in vivo environment & $\begin{array}{l}\text { Activation of peripheral } \mathrm{T} \text { cells causes } \\
\text { nonspecific deletion. Glucocorticoid mediated }\end{array}$ \\
\hline $\begin{array}{l}\text { In vivo: } \mathrm{TCR} T \mathrm{Tg} \text { with } \\
\text { injected peptide }\end{array}$ & & Intact in vivo environment & $\begin{array}{l}\text { Activation of peripheral } \mathrm{T} \text { cells causes } \\
\text { nonspecific deletion. Cytokine mediated }\end{array}$ \\
\hline $\begin{array}{l}\text { In vivo: } \mathrm{TCR} T \mathrm{Tg} \text { with } \\
\text { transgenic neo-self antigen }\end{array}$ & & Intact in vivo environment & $\begin{array}{l}\text { Early TCR expression } \\
\text { TCR expression level higher than normal } \\
\text { on thymic precursors } \\
\text { High precursor frequency/monoclonal } \\
\text { Transgenic-antigen artifacts } \\
\text { (expression pattern/level) }\end{array}$ \\
\hline $\begin{array}{l}\text { In vivo: } \mathrm{TCR} T \mathrm{~T} \text { with } \\
\text { endogenous self-antigen }\end{array}$ & & Intact in vivo environment & $\begin{array}{l}\text { Early TCR expression } \\
\text { TCR expression level higher than } \\
\text { normal on thymic precursors } \\
\text { High precursor frequency/monoclonal }\end{array}$ \\
\hline $\begin{array}{l}\text { In vivo: } \mathrm{TCR} \mathrm{Tg} \text { mixed bone } \\
\text { marrow chimeras with } \\
\text { endogenous self-antigen }\end{array}$ & & $\begin{array}{l}\text { Intact in vivo environment } \\
\text { Precursor frequency is lower }\end{array}$ & $\begin{array}{l}\text { Early TCR expression } \\
\text { TCR expression level higher than } \\
\text { normal on thymic precursors }\end{array}$ \\
\hline $\begin{array}{l}\text { In vivo: "On-time" TCR Tg } \\
\text { with endogenous self-antigen }\end{array}$ & & $\begin{array}{l}\text { Intact in vivo environment } \\
\text { Appropriate TCR timing } \\
\text { (can use in mixed chimeras to } \\
\text { obtain low precursor frequency) }\end{array}$ & $\begin{array}{l}\text { TCR expression somewhat higher } \\
\text { than normal on thymic precursors }\end{array}$ \\
\hline $\begin{array}{l}\text { In vivo: } V \beta \text { transgenics with } \\
\text { endogenous self or neo-self antigens }\end{array}$ & & $\begin{array}{l}\text { Intact in vivo environment } \\
\text { Appropriate TCR timing and level } \\
\text { Precursor frequency is lower/oligoclonal }\end{array}$ & $\begin{array}{l}\text { Inability to track cells prior to } \\
\text { selection in DP thymocytes }\end{array}$ \\
\hline
\end{tabular}

high-affinity TCR ligation [15]. However, it was more recently observed that activation of peripheral $T$ cells and their subsequent release of pro-inflammatory cytokines and stress hormones [16] could be obscuring TCR-induced death of DP thymocytes. The development of TCR transgenic mice was a major advancement in the field of thymic development and allowed researchers to examine negative selection in response to true $\mathrm{p} / \mathrm{MHC}$ stimulation. Some studies have utilized exogenous administration of peptide to induce negative selection [17], but this also has the caveat of activation of peripheral $\mathrm{T}$ cells $[18,19]$. A more physiological model has been to examine the response to endogenous high-affinity peptides, either produced transgenically (neoself-antigens) $[4,20,21]$ or naturally occurring [22, 23].

The use of different model systems has led to conflicting conclusions about the developmental stage at which thymocytes undergo clonal deletion. For example, superantigen studies have suggested that deletion occurs at the single positive (SP) stage, whereas the examination of TCR transgenics and endogenous self-antigens have suggested that deletion occurs at the transition from double negative (DN) to double positive (DP). This apparent discrepancy can be partially rectified by observation that superantigens are primarily expressed in the medulla, which is the site where SP thymocytes reside. Furthermore, the nature of transgenic TCR expression has called into question the deletion observed at the DN to DP transition. Wild type thymocytes rearrange their $\mathrm{TCR} \beta$ loci at the DN stage and if successful, they transition to the DP stage and commence rearrangement of the TCR $\alpha$ loci. Thus, thymocytes are not competent to undergo deletion until they have expressed a heterodimeric $\operatorname{TCR} \alpha \beta$ at the DP stage. However, TCR transgenic thymocytes express both TCR $\alpha$ and TCR $\beta$ chains early at the DN stage and probably undergo negative selection prematurely, which could explain the observation that deletion happens at the $\mathrm{DN}$ to DP transition. It is clear that the nature of TCR and self-antigen expression can dramatically impact the timing of clonal deletion and perhaps the molecular mechanism by which apoptosis is induced. It is therefore important to move forward by making use of the most physiological tools available. 
As an example, our laboratory recently generated a TCR transgenic mouse that recapitulates the appropriate timing of TCR $\alpha$ expression at the DP stage (the HY ${ }^{\text {cd4 }}$ model) [24]. HY ${ }^{\mathrm{cd} 4}$ thymocytes bear the same TCR as the original HY transgenic mouse made by Harold Von Boehmer's laboratory [23] and has a high affinity for a self-peptide derived from the $\mathrm{Y}$ chromosome in male mice, but because of the appropriately timed expression of the HY TCR $\alpha$ chain at the DP stage, they undergo deletion at the DP to SP transition. This is in stark contrast to when the TCR $\alpha$ chain is expressed prematurely in DN thymocytes and deletion occurs at the DN to DP transition (either in the conventional HY mouse [23] or when we utilized lck-driven Cre [24]). Other studies have utilized TCR $\beta$-only transgenic mice to eliminate nonphysiologic artifacts of transgenic TCR $\alpha$ expression [21, 25]. This approach has the added benefit of producing an oligoclonal repertoire with reduced precursor frequency of antigen-specific thymocytes, which also corrects defects in thymic architecture that are typical of conventional TCR transgenics [26, 27]. The latter study by Gallegos and Bevan also made use of the unique expression of tissue-restricted antigens (TRAs) in the medulla (explained in more detail below). This system obviates the artifacts introduced by premature transgenic TCR expression because only postpositive selection thymocytes, transitioning from the DP to SP stage and migrating to the medulla, are encountering high-affinity antigen and undergoing deletion (See Fig. 1). One lingering defect of all TCR transgenic models is the expression level of the TCR transgenes. Wild-type DP thymocytes express very little TCR on their cell surface and upregulate its expression following positive selection, whereas TCR transgenes driven off of strong promoters express at higher levels. Unfortunately, creating a TCR $\alpha$ knock-in into the endogenous locus still bears this artifact [28], although a TCR $\beta$ knock-in has not yet been created. Thus, a model for completely physiological transgenic TCR expression remains elusive. Future studies examining negative selection should strive to make use of models that have appropriately timed TCR expression, at physiological levels, with high affinity for a physiologically expressed, endogenous selfantigen. Precursor frequency of antigen-specific cells should also be minimized. Ideally, the analysis of a polyclonal repertoire should be employed; however, it is currently difficult to identify small numbers of precursors, due to the fact that DP thymocytes express low levels of TCR and are not easily distinguished by $\mathrm{p} / \mathrm{MHC}$ tetramer staining.

\section{Molecular mediators of clonal deletion}

A fundamental question of T cell development has been: How does a thymocyte distinguish between positive and negative selection ligands? The pervasive "affinity model" predicts that the kinetics of TCR binding to self-p/MHC determines this outcome. There is much support for this model, and recently, the precise threshold for this distinction based on affinity was determined for class I MHC-restricted TCRs [29]. Nonetheless, how a cell translates TCR affinity into the decision between life and death is less well understood. It has been suggested that high-affinity TCR ligation induces a conformational change in the cytoplasmic tail of $\mathrm{CD} 3 \varepsilon$, which exposes a polyproline sequence that serves as a binding site for the adapter protein Nck [30]. However, another study suggested that low-affinity interactions also expose the polyproline sequence, albeit less efficiently [31]. Recently, Mingueneau and colleagues created knock-in mice with a mutation in the $\mathrm{CD} 3$ polyproline region. Surprisingly, they found that binding of Nck does not depend on previous TCR ligation. Additionally, positive selection was affected by introduction of the mutation in two TCR transgenic models, but negative selection was not [32]. The misshapen-Nckinteracting kinase-related kinase (MINK) was also suggested to be important for the induction of negative selection [33], although this finding has not further corroborated. With respect to TCR-proximal signaling events, it has been suggested that differential activation of the extracellular signal-regulated kinase (ERK) and $c$-Jun $\mathrm{N}$-terminal kinase (JNK) pathways is important in this discrimination (discussed in depth in [34]). A recent report extended these findings by demonstrating the differential subcellular localization of Ras and mitogen-activated protein kinase signaling intermediates in response to positively and negatively selecting ligands [35]. Thus, it appears that Ras-mediated activation of the ERK pathway is dispensable for clonal deletion. Interestingly, Ras signaling is not only involved in positive selection of conventional $\mathrm{T}$ cells [36] but also in the generation of Foxp $3^{+}$Tregs [37], which seem to be selected by high affinity ligands [6]. This may be important for the decision between clonal deletion and clonal diversion. It was also recently shown that deficiency of the protein phosphatase G5PR resulted in hyperactivation of JNK and caspase 3 [38], indicating that G5PR inhibits apoptosis in the steady state and that overcoming this inhibition by G5PR is perhaps necessary for clonal deletion. A role for costimulation to induce clonal deletion has also been suggested. However, this has been controversial, likely due to use of different model systems (see [34] for a thorough review). While $\alpha \mathrm{CD} 28$ strongly costimulates apoptosis in vitro, no single costimulatory molecule has been shown to be required in all models of clonal deletion. It is possible that multiple distinct costimulatory molecules function redundantly in clonal deletion.

The signals leading to clonal deletion ultimately activate the apoptosis pathway (see [39] for a detailed review), and a number of groups have implicated the orphan nuclear 
Fig. 1 Distinct stages of clonal deletion in the thymus. DP thymocytes are positively selected in the thymic cortex when they interact with cortical thymic epithelial cells (cTEC). cTEC themselves are likely not efficient inducers of clonal deletion. However, DP thymocytes that are triggered through the TCR upregulate CCR7. This facilitates their movement toward the thymic medulla. It may also facilitate interaction with dendritic cells (DC) in the cortex (upper right box) which produce CCR7 ligands. Cortical dendritic cells are required for efficient clonal deletion of those DP thymocytes that recognize ubiquitious self-antigens. Thymocytes that recognize tissue-specific self antigens are deleted later, at the SP stage in the thymic medulla (lower right box). Medullary thymic epithelial cells (mTEC) produce tissue specific self-antigens in an AIRE dependent fashion, and can directly present to SP thymocytes. Dendritic cells, which are abundant in the medulla, can also cross present antigens for clonal deletion

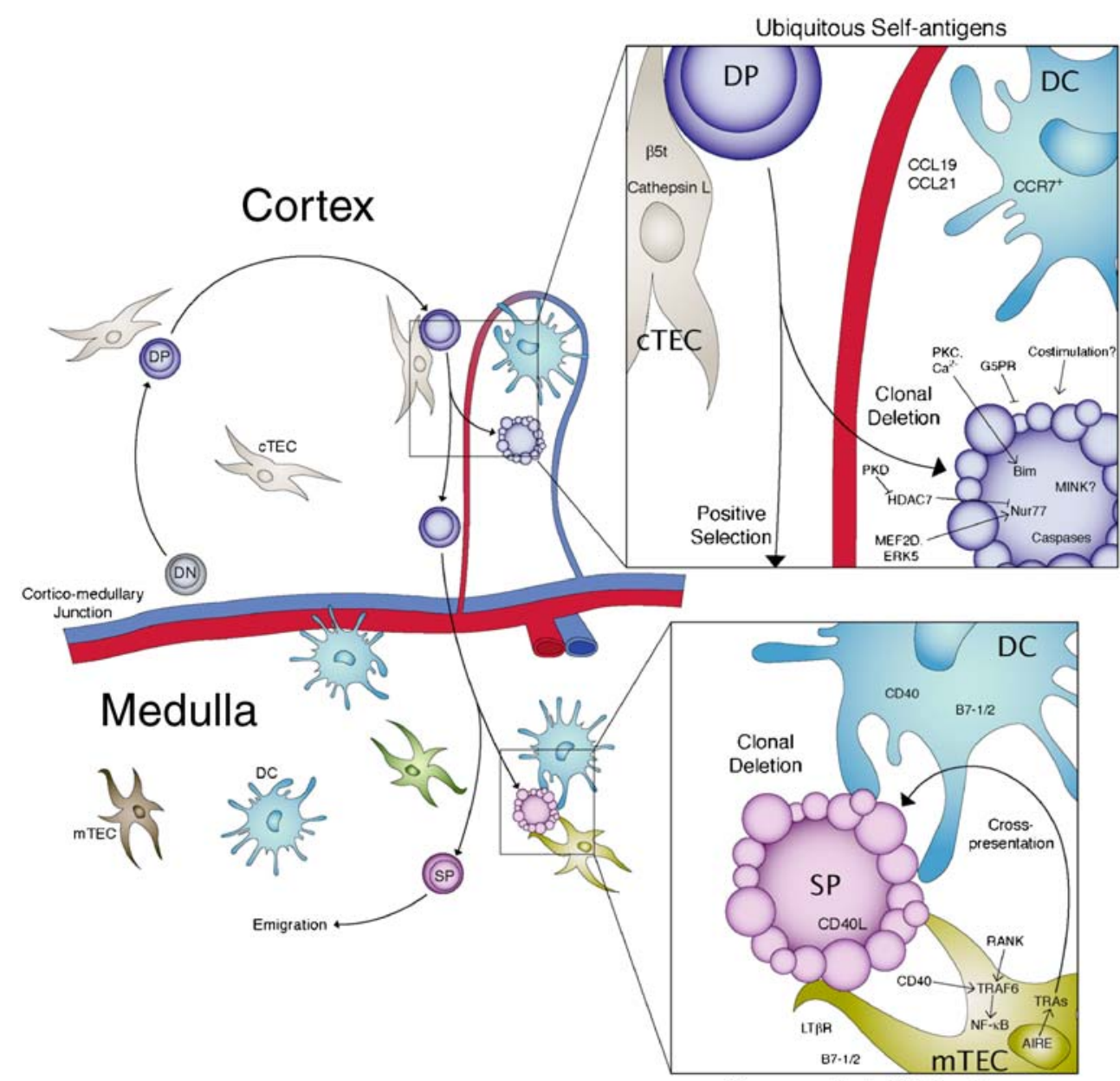

Tissue-restricted Self-antigens steroid receptor Nur77 as being necessary [40, 41]. It was shown using cultured thymocytes that myocyte enhancerbinding factor 2D (MEF2D) and ERK5 mediate transcription of Nur77 [42]. On the other hand, Nur77 expression is repressed by histone deacetylase 7 (HDAC7), and this inhibition can be overcome by TCR stimulation that activates protein kinase D1 which subsequently phosphorylates HDAC7 and promotes its nuclear export [43-45]. While it has been well documented that Nur77 is induced following a strong TCR stimulation, it is less clear how Nur77 exerts its pro-apoptotic function. It was first proposed that Nur77 acts a transcription factor to promote apoptosis [46], but a more recent report suggested that Nur77 mediates apoptosis by translocating to the mitochondria where it sequesters the anti-apoptotic molecule Bcl-2 [47]. It remains unclear if the role of Nur77 as a transcription factor is also necessary. Defining the precise role for Nur77 in negative selection has been further complicated by the observation that Nor-1, a closely related family member, can have functional redundancy with Nur77 [48].

The pro-apoptotic molecule Bim also plays a central role in clonal deletion [49]. The precise mechanisms leading to Bim induction have not been fully elucidated, although $\mathrm{Ca}^{2+}$ and protein kinase $\mathrm{C}$ were suggested to be important [50]. A number of recent reports have investigated the transcriptional profile of thymocytes undergoing negative selection [51-55]. The most recent of these, by Baldwin and Hogquist, compared the gene array data sets generated by the different groups and found surprisingly little overlap between them. Specifically, only Bim, Nur77, PD-1, and Gadd $45 \beta$ were consistently found to be upregulated. This might suggest that clonal deletion only requires a small number of genes to be newly synthesized. However, it has yet to be demonstrated that new transcription of any of these genes after the initial TCR ligation is absolutely necessary for deletion. It has been suggested that transcription of Bim is required [50], but it has also been argued that phosphorylation of Bim is the critical event in promoting clonal deletion [56].

Finally, an intriguing report recently suggested that posttranscriptional regulation of mRNA by microRNAs might be important in the distinction between positive and negative selection [57]. Li et al. showed that miR1-181a acts as an intrinsic "rheostat" to control $\mathrm{T}$ cell sensitivity in thymocytes and mature $\mathrm{T}$ cells. It is likely that miR-181a plays a role in 
setting the bandwidth for discrimination of positive and negative selection signals, and perhaps the regulation of miR181a itself or its targets plays a role in inducing apoptosis following a high-affinity TCR signal. Our understanding of the role of microRNA in T cell development is in its infancy and is likely to be even more greatly appreciated in the future as evidenced by other recent work examining DICER and microRNA in T cell development and function [58-60].

\section{Cell types that mediate clonal deletion}

Cortical thymic epithelial cells

Thymocytes interact with a variety of antigen-presenting cells during the course of their development. DN thymocytes enter the thymus at the corticomedullary junction (CMJ) and traverse outwards towards the subcapsular region where they undergo rearrangement of the TCR $\beta$ chain (Fig. 1). As DPs, they migrate randomly though a dense matrix of cortical thymic epithelial cells (cTECs), and their engagement with $\mathrm{p} / \mathrm{MHC}$ on cTECs is crucial for positive selection [61]. Whether or not cTECs are also capable of inducing negative selection is less clearly understood. A number of studies have concluded that cTECs are not capable of inducing tolerance to self-antigens [62-66]. However, there is also much data to suggest that cTECs can in fact be tolerogenic [4, 67-75]. This apparent contradiction is likely explained by the observation made by Goldman et al. that studies indicating the thymic epithelium was not capable of inducing tolerance "were done using antigens not normally expressed by thymic epithelium and/or targets derived from other tissues". They then go on to suggest that cTECs are capable of inducing tolerance to antigens expressed by cTECs, but not to all antigens expressed in the body. In addition, we have shown that cTECs are inefficient at inducing apoptosis of self-reactive thymocytes but that they are ultimately tolerogenic because they prevented the development of mature SP thymocytes [76]. We were unable to determine if cTECs induced anergy or clonal diversion of these cells, but these observations may also help reconcile the apparent contradictions in previous studies because the induction of tolerance can occur by mechanisms other than clonal deletion.

An intriguing study was recently reported that potentially changes the paradigm of cTECs in positive and negative selection [77]. In addition to the "standard" proteasome and the "immunoproteasome", Murata et al. described a novel proteasomal subunit expressed exclusively in cTECs, which they termed $\beta 5 \mathrm{t}$. This "thymoproteasome" has unique peptidase activity with reduced chymotrypsin-like activity, which is important for generating peptides with hydrophobic C-termini. Hydrophobic C-termini anchor peptides in the groove of class I MHC. Therefore, it is likely that cTECs not only generate a unique peptide repertoire but also present unstable class I MHC on their cell surface. These observations may explain why cTECs are critical for positive selection, and in fact, $\beta 5 \mathrm{t}$-deficient mice had a dramatic defect in generation of CD8 SPs. This unique feature of cTECs also potentially explains why cTECs are incapable of inducing tolerance to antigens expressed throughout the body and their poor ability to induce clonal deletion. It is interesting to speculate that a similar mechanism exists in cTECs for the generation of class II p/mHC complexes, perhaps via cathepsins $[78,79]$.

Trafficking to the medulla

The notion that cTECs are not sufficient for induction of clonal deletion is bolstered by the observation that trafficking to the medulla is necessary for achieving complete tolerance $[80,81]$ and that this migration is primarily mediated by CCR7-dependant signaling [82, 83] (See Fig. 1). Indeed, mice with medullar defects also display autoimmune phenotypes (reviewed in [84]). It is commonly believed that the medulla is a specialized anatomical location for clonal deletion due to the high density of dendritic cells (DC) and the peculiar ability of medullary thymic epithelial cells (mTECs) to ectopically express TRAs (both of which are described in further detail below). However, a defect in clonal deletion may not be sufficient to explain the lack of tolerance in previously mentioned studies. This is because the medulla has also been implicated to be important for the generation of immunoregulatory $\mathrm{T}$ cells [85-88] and for conventional $\mathrm{T}$ cells to undergo final maturation and adjustment of their TCR sensitivity to self-antigens (a process referred to as "TCR tuning") [89]. In addition, Reinhold Förster's laboratory also questioned whether or not CCR7 was the only chemokine receptor involved in corticomedullar migration [90]. While there is clearly medullar dysplasia in CCR7deficient mice and reduced medullar volume, they showed that proportionally normal numbers of CD4 SP thymocytes were found in the small pockets of medulla that remained. They concluded that a redundant mechanism exists for migration to the medulla. Importantly though, it should be noted that the majority of SPs in the medulla were CD4 SPs, and it was impossible to distinguish if these were truly developing thymocytes or another lineage of $\mathrm{CD}^{+} \mathrm{T}$ cells, such as Foxp3 ${ }^{+}$Tregs that also reside in the medulla [91] and may have an alternate homing mechanism.

Medullary thymic epithelial cells

Despite the complicating factors of Treg development, TCR tuning, and the role of CCR7-mediated chemotaxis, it is clear 
that developing thymocytes must gain access to the medulla to be screened against a panel of self-antigens uniquely expressed there (See Fig. 1). It has been shown that medullary thymic epithelial cells are capable of expressing the autoimmune regulator (AIRE), which leads to the ectopic expression of tissue-restricted antigens [92, 93]. This phenomenon of mTECs is crucial for the establishment of central tolerance as AIRE-deficient humans and mice both develop autoimmunity [94]. It has been shown that mTECs express the costimulatory molecules B7-1 and B7-2 and that direct presentation of TRAs by mTECs is sufficient to induce clonal deletion of antigen-specific thymocytes, although cross-presentation by dendritic cells also occurs [21] (discussed in further detail below).

The development of mTECs is dependent upon a population of $\mathrm{CD}^{+} \mathrm{CD}^{-}$lymphoid tissue inducer cells and receptor activator of nuclear factor $\mathrm{KB}$ (RANK)RANK ligand interactions, and their maintenance is, in part, controlled by CD40-CD40L signaling and lymphotoxin- $\beta$ receptor (LT $\beta R$; see Fig. 1) [95-97]. Furthermore, tumor necrosis factor receptor-associated factor 6 (TRAF6), which signals downstream of RANK and CD40, is also needed for mTEC development [86]. TRAF6 activates the transcription factor NF- $\mathrm{KB}$, which is also required for mTEC development [98], as is the NF-kB-inducing kinase [85] and IKB kinase $\alpha$ [99].

Recent work has also demonstrated that mTECs are a highly dynamic population with high proliferative capacity and a turnover rate of about 2 weeks $[100,101]$. It was observed that the majority of proliferating mTECs were mature, $\mathrm{UEA}-1^{+} \mathrm{MHC}$ class $\mathrm{II}^{\mathrm{hi}}$, and that these mature mTECs are the ones expressing AIRE [102]. In addition, it appears that AIRE-expressing mTECs are short-lived with rapid turnover [103]. While AIRE-dependent TRAs are found clustered throughout the genome, implying a role for epigenetics in AIRE function [104], it has also been shown that individual mTECs express a stochastic battery of TRAs, such that each mTEC is unique with respect to its antigen-presentation profile $[105,106]$. Taken together, these data paint a picture where mTECs are critical for the elimination of self-reactive thymocytes and that individual AIRE-expressing mTECs are highly diverse and turning over rapidly. As loss of tolerance to just one tissuerestricted antigen is sufficient to cause autoimmunity [107], it becomes clear that thymocytes must have ample opportunity to peruse the entire milieu of the medulla to be adequately screened for self-reactivity. We recently showed that the length of time that an SP thymocyte spends in the medulla is roughly 4-5 days [108], during which a thymocyte "tunes" its TCR and becomes refractory to apoptosis. Therefore, a short medullary residency time of SP thymocytes, in combination with the diversity and turnover of mTECs expressing TRAs, may be a weak point in the mechanism of central tolerance. Evolution has obviously created a system that prevents overt autoimmunity but bear in mind that $\mathrm{T}$ cell-driven autoimmunity is disturbingly common in the human population. Finally, the precise mechanism by which AIRE operates is not entirely understood. AIRE most likely operates as a transcription factor, but as mentioned above with regards to epigenetics, it remains possible that AIRE promotes ectopic expression of TRAs by another mechanism(s) [109]. In addition, not all TRAs are AIRE-dependent [104]; thus, another mechanism or molecule, similar to AIRE, must also exist, perhaps involving LT $\beta R$ [110].

Dendritic cells

Dogma states that TCR activation and clonal deletion are most efficiently induced by bone marrow-derived cells, and it is widely believed that dendritic cells are the principle mediator of clonal deletion. This is because DC are thought of as "professional" antigen presenting cells with high levels of class II MHC on the cell surface as well as high levels of costimulatory molecules, such as B7-1 and B7-2. Indeed, a direct role for $\mathrm{DC}$ in clonal deletion has been demonstrated $[21,111,112]$. However, the heterogeneity in thymic DC is largely underappreciated and not completely understood. It is unclear if all DC in the thymus are equal in their capacity to induce clonal deletion. Work by Donskoy and Goldschneider has shown that at least two distinct populations of thymic DCs exist: one that develops intrathymically and one that is derived from peripheral DCs migrating to the thymus [113]. It was suggested that these two populations might have functional differences in their ability to induce deletion of self-reactive thymocytes vs. clonal diversion of immunoregulatory cells. Goldschneider and Cone propose a model where intrathymically derived DC mediate clonal deletion, whereas extrathymically derived cells support the agonist selection of regulatory $\mathrm{T}$ cells (see [114] for a comprehensive review of this argument). It is important to note that the phenotype is unknown of the subset of peripheral DCs that are capable of migrating to the thymus and mediating this selection. In line with this hypothesis, it has been shown in the human thymus that a group of mTECs called Hassall's corpuscles produces TSLP (thymic stromal lymphopoietin) and this allows DC to induce the proliferation and differentiation of Foxp $^{+}$Tregs [115]. Conversely, it was more recently demonstrated that antigen-loaded, splenic DC were capable of homing to the thymus and inducing deletion of antigenspecific thymocytes [116]. More detailed analysis of the phenotype of the DC migrating to the thymus was also performed, and these DC included all subsets of splenic DC that were present at the time of injection, although LPSmatured DC showed a reduced capacity to home to the 
thymus. It may be that the ability of peripheral DC to migrate to the thymus and induce deletion vs. agonist selection might not be mutually exclusive and may depend upon the specific environmental and experimental conditions. It is also possible that different subsets of peripheral DC are capable of mediating the different selection outcomes.

As potential support for the latter hypothesis, Ken Shortman's laboratory has shown that, in addition to intrathymically- and extrathymically derived DCs, at least three other DC subsets can be identified based upon cell surface markers (reviewed in [117]). Their data showed an initial division of DC into two populations, $35 \%$ of which are plasmacytoid DC (pDC) and the remaining $65 \%$ are conventional DC (cDC). The distinction between these two populations is based on expression of CD11c and CD45RA, with pDC being CD11 $\mathrm{c}^{\text {int }}$ and CD45RA ${ }^{+}$, and cDC being CD11 $\mathrm{c}^{\text {hi }}$ and CD45RA ${ }^{-}$. The majority of $\mathrm{pDC}$ are $\mathrm{Ly} 6 \mathrm{c}^{+}$, although a small fraction of $\mathrm{Ly}^{-} \mathrm{c}^{-}$can also be found. Similar to $\mathrm{pDC}$ in the spleen and lymph node, some thymic pDC can express CD4 and/or $\mathrm{CD} 8 \alpha$, but unlike peripheral pDC, they express high levels of TLR7 and 9, but only low levels of TLR 2, 3, and 4. Also similar to peripheral $\mathrm{pDC}$, thymic $\mathrm{pDC}$ express low levels of MHC class II and costimulatory molecules and can take up antigen by endocytosis but not phagocytosis. Thus, pDC are weak stimulators of $\mathrm{T}$ cells. On the other hand, all conventional DC are MHC class II+ and the majority are $\mathrm{CD} 8 \alpha \alpha^{+}$. Similar to the minority population of $\mathrm{CD} 8^{+} \mathrm{DC}$ in the spleen and lymph node, this population in the thymus is $\mathrm{DEC}-205^{+}(\mathrm{CD} 205)$ and $\mathrm{CD} 11 \mathrm{~b}^{-}$. However, unlike peripheral $\mathrm{CD} 8 \alpha^{+} \mathrm{DC}$, some thymic $\mathrm{CD} 8 \alpha^{+} \mathrm{cDC}$ also express BP-1, although no functional difference has yet been shown based upon this distinction. Conventional DC can be further subdivided by their expression of CD8 $\alpha$ and $\operatorname{Sirp} \alpha$ (CD172a). CD $8 \alpha^{\text {lo }}$ Sirp $\alpha^{+}$DCs account for $20 \%$ of the thymic $\mathrm{cDC}$ population, and similar to splenic $\mathrm{CD} 8 \alpha^{-}$ $\mathrm{DC}$, this population is also CD11 $b^{\text {int }}$. While thymic $\mathrm{cDC}$ express the costimulatory molecules $\mathrm{B} 7-1$ and $\mathrm{B} 7-2$ at slightly higher levels than their peripheral counterparts, for the most part, they appear to be immature because they are capable of phagocytic or endocytic uptake of antigens and process and present them on MHC class II. In addition, they upregulate expression of MHC class II and costimulatory molecules following activation. It is not entirely clear how this classification of thymic DC aligns with the division created by the Goldschneider laboratory as to the origin of these cell types. It seems that most of CD $8 \alpha^{+}$cDC develop intrathymically from a lymphoid prothymocyte precursor, whereas extrathymically derived DC include the $\mathrm{CD} 8 \alpha^{-}$ DC population, likely of myeloid origin.

Finally, it is well documented that the majority of thymic DCs are found in the medulla, and therefore, it is thought that the anatomical location of clonal deletion is at the CMJ or in the medulla. However, we and others have noted the sparse but distinct presence of DC in the cortex of the thymus (See Fig. 1). This often-overlooked observation raises the possibility that cortical DC may be sufficient to mediate clonal deletion. Indeed, we have recently shown that clonal deletion to ubiquitous self-antigens can occur in the cortex, with no involvement of the medulla [76]. Furthermore, we found that thymocytes undergoing this process were preferentially in contact with DC present in the cortex and that conditional ablation of DC significantly impaired clonal deletion of antigen-specific cells. The fact that clonal deletion to ubiquitous self-antigens can occur in the cortex does not preclude the requirement of migration to the medulla and clonal deletion to TRAs. It does, however, expand our thinking as to the mechanism underlying clonal deletion. It is unknown if any phenotypic differences exist between cortical and medullar DC, or if any subset(s) of DC discussed previously reside preferentially in the cortex or the medulla. It was recently shown that most cortical DC are found in close association with small blood capillaries that express CCR7 ligands ([118] and our unpublished data). As positively selected thymocytes also express CCR7, it is interesting to speculate that this exists as an initial mechanism for screening thymocytes for clonal deletion. It also raises the possibility that thymocyte migration to the medulla does not occur randomly but that $\mathrm{CCR} 7^{+}$cells travel along blood capillaries, which ultimately lead to the CMJ. Finally, given that cTEC are not efficient at inducing clonal deletion and DC are, it is likely that a second signal that can be delivered by a DC but not a cTEC is necessary to induce apoptosis. We have observed that cortical DCs express B7-2, and it is tempting to think that this is the second signal. However, as discussed previously, there is no absolute role for costimulation by B7-2, although it has been shown that complete deletion of superantigen-reactive cells requires $\mathrm{B} 7-1 / 2$ and $\mathrm{CD} 28$ interaction [119]. Therefore, it remains possible that $\mathrm{B} 7-1$ and B7-2 play a role in clonal deletion, but it is probable that other costimulatory molecules also exist.

In conclusion, recent advancements have allowed researchers to gain a deeper understanding of the process of clonal deletion. We are finally beginning to understand the molecular pathways that are necessary for the elimination of self-reactive thymocytes, as well as the cellular players that contribute to this process. As the field moves ahead, it is important to develop and use the most physiological tools possible and to consider the intricate anatomical microenvironments of the thymus in order to gain a clear understanding of clonal deletion.

Open Access This article is distributed under the terms of the Creative Commons Attribution Noncommercial License which permits any noncommercial use, distribution, and reproduction in any medium, provided the original author(s) and source are credited. 


\section{References}

1. McGargill MA, Derbinski JM, Hogquist KA (2000) Receptor editing in developing $\mathrm{T}$ cells. Nat Immunol 1:336-341. doi: $10.1038 / 79790$

2. Santori FR, Arsov I, Lilic M, Vukmanovic S (2002) Editing autoreactive TCR enables efficient positive selection. J Immunol 169:1729-1734

3. Wang F, Huang CY, Kanagawa O (1998) Rapid deletion of rearranged $\mathrm{T}$ cell antigen receptor (TCR) Valpha-Jalpha segment by secondary rearrangement in the thymus: role of continuous rearrangement of TCR alpha chain gene and positive selection in the $\mathrm{T}$ cell repertoire formation. Proc Natl Acad Sci U S A 95:11834-11839. doi:10.1073/pnas.95.20.11834

4. Mayerova D, Hogquist KA (2004) Central tolerance to selfantigen expressed by cortical epithelial cells. J Immunol 172:851-856

5. Hammerling GJ, Schonrich G, Momburg F, Auphan N, Malissen M, Malissen B, Schmitt-Verhulst AM, Arnold B (1991) Nondeletional mechanisms of peripheral and central tolerance: studies with transgenic mice with tissue-specific expression of a foreign MHC class I antigen. Immunol Rev 122:47-67. doi:10.1111/j.1600-065X.1991.tb00596.x

6. Liston A, Rudensky AY (2007) Thymic development and peripheral homeostasis of regulatory T cells. Curr Opin Immunol 19:176-185. doi:10.1016/j.coi.2007.02.005

7. MacDonald HR, Mycko MP (2007) Development and selection of Valpha 14i NKT cells. Curr Top Microbiol Immunol 314:195212. doi:10.1007/978-3-540-69511-0 8

8. Baldwin TA, Hogquist KA, Jameson SC (2004) The fourth way? Harnessing aggressive tendencies in the thymus. J Immunol 173:6515-6520

9. Lambolez F, Kronenberg M, Cheroutre H (2007) Thymic differentiation of TCR alpha beta(+) CD8 alpha alpha(+) IELs. Immunol Rev 215:178-188. doi:10.1111/j.1600-065X.2006.00488.x

10. Burnet FM (1957) A modification of Jerne's theory of antibody production using the concept of clonal selection. Aust J Sci 20:67

11. Kappler JW, Roehm N, Marrack P (1987) T cell tolerance by clonal elimination in the thymus. Cell 49:273-280. doi:10.1016/ 0092-8674(87)90568-X

12. Smith CA, Williams GT, Kingston R, Jenkinson EJ, Owen JJ (1989) Antibodies to CD3/T-cell receptor complex induce death by apoptosis in immature $\mathrm{T}$ cells in thymic cultures. Nature 337:181-184. doi:10.1038/337181a0

13. Jenkinson EJ, Kingston R, Smith CA, Williams GT, Owen JJ (1989) Antigen-induced apoptosis in developing $\mathrm{T}$ cells: a mechanism for negative selection of the T cell receptor repertoire. Eur J Immunol 19:2175-2177. doi:10.1002/eji.1830191132

14. Swat W, Ignatowicz L, von Boehmer H, Kisielow P (1991) Clonal deletion of immature CD4+8+ thymocytes in suspension culture by extrathymic antigen-presenting cells. Nature 351:150153. doi:10.1038/351150a0

15. Shi YF, Bissonnette RP, Parfrey N, Szalay M, Kubo RT, Green DR (1991) In vivo administration of monoclonal antibodies to the CD3 T cell receptor complex induces cell death (apoptosis) in immature thymocytes. J Immunol 146:3340-3346

16. Brewer JA, Kanagawa O, Sleckman BP, Muglia LJ (2002) Thymocyte apoptosis induced by $\mathrm{T}$ cell activation is mediated by glucocorticoids in vivo. J Immunol 169:1837-1843

17. Murphy KM, Heimberger AB, Loh DY (1990) Induction by antigen of intrathymic apoptosis of CD4+CD8+TCRlo thymocytes in vivo. Science (New York, NY) 250:1720-1723

18. Martin S, Bevan MJ (1997) Antigen-specific and nonspecific deletion of immature cortical thymocytes caused by antigen injection. Eur J Immunol 27:2726-2736. doi:10.1002/eji.1830271037
19. Zhan Y, Purton JF, Godfrey DI, Cole TJ, Heath WR, Lew AM(2003) Without peripheral interference, thymic deletion is mediated in a cohort of double-positive cells without classical activation. Proc Natl Acad Sci U S A 100:1197-1202. doi:10.1073/pnas.0237316100

20. Baldwin KK, Trenchak BP, Altman JD, Davis MM (1999) Negative selection of T cells occurs throughout thymic development. J Immunol 163:689-698

21. Gallegos AM, Bevan MJ (2004) Central tolerance to tissuespecific antigens mediated by direct and indirect antigen presentation. J Exp Med 200:1039-1049. doi:10.1084/jem.20041457

22. Sha WC, Nelson CA, Newberry RD, Kranz DM, Russell JH, Loh DY (1988) Positive and negative selection of an antigen receptor on $\mathrm{T}$ cells in transgenic mice. Nature 336:73-76. doi: $10.1038 / 336073 \mathrm{a} 0$

23. Kisielow P, Bluthmann H, Staerz UD, Steinmetz M, von Boehmer H (1988) Tolerance in T-cell-receptor transgenic mice involves deletion of nonmature $\mathrm{CD} 4+8+$ thymocytes. Nature 333:742-746. doi:10.1038/333742a0

24. Baldwin TA, Sandau MM, Jameson SC, Hogquist KA (2005) The timing of TCR alpha expression critically influences T cell development and selection. J Exp Med 202:111-121. doi:10.1084/jem.20050359

25. Bouneaud C, Kourilsky P, Bousso P (2000) Impact of negative selection on the $\mathrm{T}$ cell repertoire reactive to a self-peptide: a large fraction of $\mathrm{T}$ cell clones escapes clonal deletion. Immunity 13:829-840. doi:10.1016/S1074-7613(00)00080-7

26. Canelles M, Park ML, Schwartz OM, Fowlkes BJ (2003) The influence of the thymic environment on the CD4-versus-CD8 T lineage decision. Nat Immunol 4:756-764. doi:10.1038/ni953

27. Goverman J, Brabb T, Huseby ES, Farr AG (1997) TCR signaling regulates thymic organization: lessons from TCRtransgenic mice. Immunol Today 18:204-208. doi:10.1016/ S0167-5699(97)01055-4

28. Buch T, Rieux-Laucat F, Forster I, Rajewsky K (2002) Failure of HYspecific thymocytes to escape negative selection by receptor editing. Immunity 16:707-718. doi:10.1016/S1074-7613(02)00312-6

29. Naeher D, Daniels MA, Hausmann B, Guillaume P, Luescher I, Palmer E (2007) A constant affinity threshold for T cell tolerance. J Exp Med 204:2553-2559. doi:10.1084/jem.20070254

30. Risueno RM, van Santen HM, Alarcon B (2006) A conformational change senses the strength of $\mathrm{T}$ cell receptor-ligand interaction during thymic selection. Proc Natl Acad Sci U S A 103:9625-9630. doi:10.1073/pnas.0601785103

31. Gil D, Schrum AG, Alarcon B, Palmer E (2005) T cell receptor engagement by peptide-MHC ligands induces a conformational change in the CD3 complex of thymocytes. J Exp Med 201:517522. doi:10.1084/jem.20042036

32. Mingueneau M, Sansoni A, Gregoire C, Roncagalli R, Aguado E, Weiss A, Malissen M, Malissen B (2008) The proline-rich sequence of $\mathrm{CD} 3$ epsilon controls $\mathrm{T}$ cell antigen receptor expression on and signaling potency in preselection CD4+CD8 + thymocytes. Nat Immunol 9:522-532. doi:10.1038/ni.1608

33. McCarty N, Paust S, Ikizawa K, Dan I, Li X, Cantor H (2005) Signaling by the kinase MINK is essential in the negative selection of autoreactive thymocytes. Nat Immunol 6:65-72. doi:10.1038/ni1145

34. Palmer E (2003) Negative selection - clearing out the bad apples from the T-cell repertoire. Natl Rev 3:383-391

35. Daniels MA, Teixeiro E, Gill J, Hausmann B, Roubaty D, Holmberg K, Werlen G, Hollander GA, Gascoigne NR, Palmer E (2006) Thymic selection threshold defined by compartmentalization of Ras/MAPK signalling. Nature 444:724-729. doi:10.1038/nature05269

36. Priatel JJ, Chen X, Dhanji S, Abraham N, Teh HS (2006) RasGRP1 transmits prodifferentiation TCR signaling that is crucial for CD4 T cell development. J Immunol 177:1470-1480 
37. Chen X, Priatel JJ, Chow MT, Teh HS (2008) Preferential development of CD4 and CD8 T regulatory cells in RasGRP1deficient mice. J Immunol 180:5973-5982

38. Xing Y, Wang X, Igarashi H, Kawamoto H, Sakaguchi N (2008) Protein phosphatase subunit G5PR that regulates the JNKmediated apoptosis signal is essential for the survival of CD4 and CD8 double-positive thymocytes. Mol Immunol 45:20282037. doi:10.1016/j.molimm.2007.10.028

39. Strasser A, Puthalakath H, O'Reilly LA, Bouillet P (2008) What do we know about the mechanisms of elimination of autoreactive $\mathrm{T}$ and $\mathrm{B}$ cells and what challenges remain. Immunol Cell Biol 86:57-66. doi:10.1038/sj.icb.7100141

40. Cho HJ, Edmondson SG, Miller AD, Sellars M, Alexander ST, Somersan S, Punt JA (2003) Cutting edge: identification of the targets of clonal deletion in an unmanipulated thymus. J Immunol 170:10-13

41. Calnan BJ, Szychowski S, Chan FK, Cado D, Winoto A (1995) A role for the orphan steroid receptor Nur77 in apoptosis accompanying antigen-induced negative selection. Immunity 3:273-282. doi:10.1016/1074-7613(95)90113-2

42. Kasler HG, Victoria J, Duramad O, Winoto A (2000) ERK5 is a novel type of mitogen-activated protein kinase containing a transcriptional activation domain. Mol Cell Biol 20:8382-8389. doi:10.1128/MCB.20.22.8382-8389.2000

43. Dequiedt F, Van Lint J, Lecomte E, Van Duppen V, Seufferlein T, Vandenheede JR, Wattiez R, Kettmann R (2005) Phosphorylation of histone deacetylase 7 by protein kinase $\mathrm{D}$ mediates $\mathrm{T}$ cell receptor-induced Nur77 expression and apoptosis. J Exp Med 201:793-804. doi:10.1084/jem.20042034

44. Parra M, Kasler H, McKinsey TA, Olson EN, Verdin E (2005) Protein kinase D1 phosphorylates HDAC7 and induces its nuclear export after T-cell receptor activation. J Biol Chem 280:13762-13770. doi:10.1074/jbc.M413396200

45. Dequiedt F, Kasler H, Fischle W, Kiermer V, Weinstein M, Herndier BG, Verdin E (2003) HDAC7, a thymus-specific class II histone deacetylase, regulates Nur77 transcription and TCRmediated apoptosis. Immunity 18:687-698. doi:10.1016/S10747613(03)00109-2

46. Kuang AA, Cado D, Winoto A (1999) Nur77 transcription activity correlates with its apoptotic function in vivo. Eur J Immunol 29:3722-3728. doi:10.1002/(SICI)1521-4141(199911) 29:11<3722::AID-IMMU3722>3.0.CO;2-N

47. Thompson J, Winoto A (2008) During negative selection, Nur77 family proteins translocate to mitochondria where they associate with Bcl-2 and expose its proapoptotic BH3 domain. J Exp Med 205:1029-1036. doi:10.1084/jem.20080101

48. Cheng LE, Chan FK, Cado D, Winoto A (1997) Functional redundancy of the Nur77 and Nor-1 orphan steroid receptors in T-cell apoptosis. EMBO J 16:1865-1875. doi:10.1093/emboj/ 16.8.1865

49. Bouillet P, Purton JF, Godfrey DI, Zhang LC, Coultas L, Puthalakath H, Pellegrini M, Cory S, Adams JM, Strasser A (2002) BH3-only Bcl-2 family member Bim is required for apoptosis of autoreactive thymocytes. Nature 415:922-926. doi:10.1038/415922a

50. Cante-Barrett K, Gallo EM, Winslow MM, Crabtree GR (2006) Thymocyte negative selection is mediated by protein kinase Cand $\mathrm{Ca} 2+-$-dependent transcriptional induction of bim. J Immunol 176:2299-2306

51. Baldwin TA, Hogquist KA (2007) Transcriptional analysis of clonal deletion in vivo. J Immunol 179:837-844

52. Liston A, Hardy K, Pittelkow Y, Wilson SR, Makaroff LE, Fahrer AM, Goodnow CC (2007) Impairment of organ-specific $\mathrm{T}$ cell negative selection by diabetes susceptibility genes: genomic analysis by mRNA profiling. Genome Biol 8:R12. doi:10.1186/gb-2007-8-1-r12
53. Liston A, Lesage S, Gray DH, O'Reilly LA, Strasser A, Fahrer AM, Boyd RL, Wilson J, Baxter AG, Gallo EM, Crabtree GR, Peng K, Wilson SR, Goodnow CC (2004) Generalized resistance to thymic deletion in the NOD mouse; a polygenic trait characterized by defective induction of Bim. Immunity 21:817-830

54. Zucchelli S, Holler P, Yamagata T, Roy M, Benoist C, Mathis D (2005) Defective central tolerance induction in NOD mice: genomics and genetics. Immunity 22:385-396. doi:10.1016/j. immuni.2005.01.015

55. DeRyckere D, Mann DL, DeGregori J (2003) Characterization of transcriptional regulation during negative selection in vivo. $\mathrm{J}$ Immunol 171:802-811

56. Bunin A, Khwaja FW, Kersh GJ (2005) Regulation of Bim by TCR signals in CD4/CD8 double-positive thymocytes. J Immunol 175:1532-1539

57. Li QJ, Chau J, Ebert PJ, Sylvester G, Min H, Liu G, Braich R, Manoharan M, Soutschek J, Skare P, Klein LO, Davis MM, Chen CZ (2007) miR-181a is an intrinsic modulator of T cell sensitivity and selection. Cell 129:147-161. doi:10.1016/j.cell.2007.03.008

58. Muljo SA, Ansel KM, Kanellopoulou C, Livingston DM, Rao A, Rajewsky K (2005) Aberrant T cell differentiation in the absence of Dicer. J Exp Med 202:261-269. doi:10.1084/jem.20050678

59. Cobb BS, Hertweck A, Smith J, O'Connor E, Graf D, Cook T, Smale ST, Sakaguchi S, Livesey FJ, Fisher AG, Merkenschlager M (2006) A role for Dicer in immune regulation. J Exp Med 203:2519-2527. doi:10.1084/jem.20061692

60. Turner M, Vigorito E (2008) Regulation of B- and T-cell differentiation by a single microRNA. Biochem Soc Trans 36:531-533. doi:10.1042/BST0360531

61. Anderson G, Lane PJ, Jenkinson EJ (2007) Generating intrathymic microenvironments to establish T-cell tolerance. Natl Rev 7:954-963

62. von Boehmer H, Hafen K (1986) Minor but not major histocompatibility antigens of thymus epithelium tolerize precursors of cytolytic T cells. Nature 320:626-628. doi:10.1038/320626a0

63. Laufer TM, DeKoning J, Markowitz JS, Lo D, Glimcher LH (1996) Unopposed positive selection and autoreactivity in mice expressing class II MHC only on thymic cortex. Nature 383:8185. doi:10.1038/383081a0

64. Capone M, Romagnoli P, Beermann F, MacDonald HR, van Meerwijk JP (2001) Dissociation of thymic positive and negative selection in transgenic mice expressing major histocompatibility complex class I molecules exclusively on thymic cortical epithelial cells. Blood 97:1336-1342. doi:10.1182/blood.V97.5.1336

65. Webb SR, Sprent J (1990) Tolerogenicity of thymic epithelium. Eur J Immunol 20:2525-2528. doi:10.1002/eji.1830201127

66. Takeuchi M, Iwasaki A, Nomoto K, Yoshikai Y (1992) Rat thymic epithelium positively selects mouse $\mathrm{T}$ cells with specificity for rat MHC class II antigens but fails to induce detectable tolerance in the mouse $\mathrm{T}$ cells to the rat $\mathrm{MHC}$ antigens. Immunobiology 186:421-434

67. Allison J, Mullbacher A, Cox K, Morahan G, Boyd R, Scollay R, Blanden RV, Miller JF (1990) Selection of the T-cell repertoire in transgenic mice expressing a transplantation antigen in distinct thymus subsets. Proc Biol Sci 241:170-178

68. Bonomo A, Matzinger P (1993) Thymus epithelium induces tissue-specific tolerance. J Exp Med 177:1153-1164. doi:10.1084/ jem.177.4.1153

69. Carlow DA, Teh SJ, Teh HS (1992) Altered thymocyte development resulting from expressing a deleting ligand on selecting thymic epithelium. J Immunol 148:2988-2995

70. Hoffmann MW, Heath WR, Ruschmeyer D, Miller JF (1995) Deletion of high-avidity T cells by thymic epithelium. Proc Natl Acad Sci U S A 92:9851-9855. doi:10.1073/pnas.92.21.9851

71. Jordan RK, Robinson JH, Hopkinson NA, House KC, Bentley AL (1985) Thymic epithelium and the induction of transplantation tolerance in nude mice. Nature 314:454-456. doi:10.1038/314454a0 
72. Le Douarin NM, Corbel C, Martin C, Coltey M, Salaun J (1989) Induction of tolerance by embryonic thymic epithelial grafts in birds and mammals. Cold Spring Harb Symp Quant Biol 54(Pt 2):777-787

73. Modigliani Y, Thomas-Vaslin V, Bandeira A, Coltey M, Le Douarin NM, Coutinho A, Salaun J (1995) Lymphocytes selected in allogeneic thymic epithelium mediate dominant tolerance toward tissue grafts of the thymic epithelium haplotype. Proc Natl Acad Sci U S A 92:7555-7559. doi:10.1073/pnas.92.16.7555

74. Schonrich G, Momburg F, Hammerling GJ, Arnold B (1992) Anergy induced by thymic medullary epithelium. Eur J Immunol 22:1687-1691. doi:10.1002/eji.1830220704

75. Goldman KP, Park CS, Kim M, Matzinger P, Anderson CC (2005) Thymic cortical epithelium induces self tolerance. Eur J Immunol 35:709-717. doi:10.1002/eji.200425675

76. McCaughtry TM, Baldwin TA, Wilken MS, Hogquist KA (2008) Clonal deletion of thymocytes can occur in the cortex with no involvement of the medulla. J Exp Med (in press)

77. Murata S, Sasaki K, Kishimoto T, Niwa S, Hayashi H, Takahama Y, Tanaka K (2007) Regulation of CD8+ T cell development by thymus-specific proteasomes. Science (New York, NY) 316:1349-1353

78. Honey K, Nakagawa T, Peters C, Rudensky A (2002) Cathepsin $\mathrm{L}$ regulates $\mathrm{CD} 4+\mathrm{T}$ cell selection independently of its effect on invariant chain: a role in the generation of positively selecting peptide ligands. J Exp Med 195:1349-1358. doi:10.1084/ jem.20011904

79. Honey K, Rudensky AY (2003) Lysosomal cysteine proteases regulate antigen presentation. Natl Rev 3:472-482

80. Kurobe H, Liu C, Ueno T, Saito F, Ohigashi I, Seach N, Arakaki R, Hayashi Y, Kitagawa T, Lipp M, Boyd RL, Takahama Y (2006) CCR7-dependent cortex-to-medulla migration of positively selected thymocytes is essential for establishing central tolerance. Immunity 24:165-177. doi:10.1016/j.immuni.2005.12.011

81. Zhu M, Chin RK, Tumanov AV, Liu X, Fu YX (2007) Lymphotoxin beta receptor is required for the migration and selection of autoreactive $\mathrm{T}$ cells in thymic medulla. J Immunol 179:8069-8075

82. Ueno T, Saito F, Gray DH, Kuse S, Hieshima K, Nakano H, Kakiuchi T, Lipp M, Boyd RL, Takahama Y (2004) CCR7 signals are essential for cortex-medulla migration of developing thymocytes. J Exp Med 200:493-505. doi:10.1084/jem. 20040643

83. Kwan J, Killeen N (2004) CCR7 directs the migration of thymocytes into the thymic medulla. J Immunol 172:3999-4007

84. Hogquist KA, Baldwin TA, Jameson SC (2005) Central tolerance: learning self-control in the thymus. Natl Rev 5:772-782

85. Kajiura F, Sun S, Nomura T, Izumi K, Ueno T, Bando Y, Kuroda N, Han H, Li Y, Matsushima A, Takahama Y, Sakaguchi S, Mitani T, Matsumoto M (2004) NF-kappa B-inducing kinase establishes self-tolerance in a thymic stroma-dependent manner. J Immunol 172:2067-2075

86. Akiyama T, Maeda S, Yamane S, Ogino K, Kasai M, Kajiura F, Matsumoto M, Inoue J (2005) Dependence of self-tolerance on TRAF6-directed development of thymic stroma. Science (New York, NY) 308:248-251

87. Nakagawa K, Iwabuchi K, Ogasawara K, Ato M, Kajiwara M, Nishihori H, Iwabuchi C, Ishikura H, Good RA, Onoe K (1997) Generation of NK1.1+ T cell antigen receptor alpha/beta+ thymocytes associated with intact thymic structure. Proc Natl Acad Sci U S A 94:2472-2477. doi:10.1073/pnas.94.6.2472

88. Bensinger SJ, Bandeira A, Jordan MS, Caton AJ, Laufer TM (2001) Major histocompatibility complex class II-positive cortical epithelium mediates the selection of CD4(+)25(+) immunoregulatory T cells. J Exp Med 194:427-438. doi:10.1084/jem. 194.4.427
89. Eck SC, Zhu P, Pepper M, Bensinger SJ, Freedman BD, Laufer TM (2006) Developmental alterations in thymocyte sensitivity are actively regulated by MHC class II expression in the thymic medulla. J Immunol 176:2229-2237

90. Davalos-Misslitz AC, Worbs T, Willenzon S, Bernhardt G, Forster R (2007) Impaired responsiveness to T-cell receptor stimulation and defective negative selection of thymocytes in CCR7-deficient mice. Blood 110:4351-4359. doi:10.1182/ blood-2007-01-070284

91. Fontenot JD, Dooley JL, Farr AG, Rudensky AY (2005) Developmental regulation of Foxp3 expression during ontogeny. J Exp Med 202:901-906. doi:10.1084/jem.20050784

92. Anderson MS, Venanzi ES, Klein L, Chen Z, Berzins SP, Turley SJ, von Boehmer H, Bronson R, Dierich A, Benoist C, Mathis D (2002) Projection of an immunological self shadow within the thymus by the aire protein. Science (New York, NY) 298:1395-1401

93. Liston A, Lesage S, Wilson J, Peltonen L, Goodnow CC (2003) Aire regulates negative selection of organ-specific T cells. Nat Immunol 4:350-354. doi:10.1038/ni906

94. Cheng MH, Shum AK, Anderson MS (2007) What's new in the Aire? Trends Immunol 28:321-327. doi:10.1016/j.it.2007.05.004

95. White AJ, Withers DR, Parnell SM, Scott HS, Finke D, Lane PJ, Jenkinson EJ, Anderson G (2008) Sequential phases in the development of Aire-expressing medullary thymic epithelial cells involve distinct cellular input. Eur J Immunol 38:942947. doi:10.1002/eji.200738052

96. Rossi SW, Kim MY, Leibbrandt A, Parnell SM, Jenkinson WE, Glanville SH, McConnell FM, Scott HS, Penninger JM, Jenkinson EJ, Lane PJ, Anderson G (2007) RANK signals from CD4(+)3(-) inducer cells regulate development of Aire-expressing epithelial cells in the thymic medulla. J Exp Med 204:1267-1272. doi:10.1084/jem.20062497

97. Boehm T, Scheu S, Pfeffer K, Bleul CC (2003) Thymic medullary epithelial cell differentiation, thymocyte emigration, and the control of autoimmunity require lympho-epithelial cross talk via LTbetaR. J Exp Med 198:757-769. doi:10.1084/jem.20030794

98. Burkly L, Hession C, Ogata L, Reilly C, Marconi LA, Olson D, Tizard R, Cate R, Lo D (1995) Expression of relB is required for the development of thymic medulla and dendritic cells. Nature 373:531-536. doi:10.1038/373531a0

99. Kinoshita D, Hirota F, Kaisho T, Kasai M, Izumi K, Bando Y, Mouri Y, Matsushima A, Niki S, Han H, Oshikawa K, Kuroda N, Maegawa M, Irahara M, Takeda K, Akira S, Matsumoto M (2006) Essential role of IkappaB kinase alpha in thymic organogenesis required for the establishment of self-tolerance. J Immunol 176:3995-4002

100. Gabler J, Arnold J, Kyewski B (2007) Promiscuous gene expression and the developmental dynamics of medullary thymic epithelial cells. Eur J Immunol 37:3363-3372. doi:10.1002/ eji.200737131

101. Gillard GO, Farr AG (2006) Features of medullary thymic epithelium implicate postnatal development in maintaining epithelial heterogeneity and tissue-restricted antigen expression. J Immunol 176:5815-5824

102. Hubert FX, Kinkel SA, Webster KE, Cannon P, Crewther PE, Proeitto AI, Wu L, Heath WR, Scott HS (2008) A specific antiAire antibody reveals aire expression is restricted to medullary thymic epithelial cells and not expressed in periphery. J Immunol 180:3824-3832

103. Gray D, Abramson J, Benoist C, Mathis D (2007) Proliferative arrest and rapid turnover of thymic epithelial cells expressing Aire. J Exp Med 204:2521-2528. doi:10.1084/jem.20070795

104. Johnnidis JB, Venanzi ES, Taxman DJ, Ting JP, Benoist CO, Mathis DJ (2005) Chromosomal clustering of genes controlled by the aire transcription factor. Proc Natl Acad Sci U S A 102:7233-7238. doi:10.1073/pnas.0502670102 
105. Derbinski J, Pinto S, Rosch S, Hexel K, Kyewski B (2008) Promiscuous gene expression patterns in single medullary thymic epithelial cells argue for a stochastic mechanism. Proc Natl Acad Sci U S A 105:657-662. doi:10.1073/pnas.0707486105

106. Derbinski J, Schulte A, Kyewski B, Klein L (2001) Promiscuous gene expression in medullary thymic epithelial cells mirrors the peripheral self. Nat Immunol 2:1032-1039. doi:10.1038/ni723

107. DeVoss J, Hou Y, Johannes K, Lu W, Liou GI, Rinn J, Chang H, Caspi RR, Fong L, Anderson MS (2006) Spontaneous autoimmunity prevented by thymic expression of a single self-antigen. J Exp Med 203:2727-2735. doi:10.1084/jem.20061864

108. McCaughtry TM, Wilken MS, Hogquist KA (2007) Thymic emigration revisited. J Exp Med 204:2513-2520. doi:10.1084/ jem.20070601

109. Anderson MS, Venanzi ES, Chen Z, Berzins SP, Benoist C, Mathis D (2005) The cellular mechanism of Aire control of T cell tolerance. Immunity 23:227-239. doi:10.1016/j.immuni.2005.07.005

110. Seach N, Ueno T, Fletcher AL, Lowen T, Mattesich $M$, Engwerda CR, Scott HS, Ware CF, Chidgey AP, Gray DH, Boyd RL (2008) The lymphotoxin pathway regulates Aireindependent expression of ectopic genes and chemokines in thymic stromal cells. J Immunol 180:5384-5392

111. Viret C, Sant'Angelo DB, He X, Ramaswamy H, Janeway CA Jr (2001) A role for accessibility to self-peptide-self-MHC complexes in intrathymic negative selection. J Immunol 166:4429-4437

112. Brocker T (1999) The role of dendritic cells in T cell selection and survival. J Leukoc Biol 66:331-335
113. Donskoy E, Goldschneider I (2003) Two developmentally distinct populations of dendritic cells inhabit the adult mouse thymus: demonstration by differential importation of hematogenous precursors under steady state conditions. J Immunol $170: 3514-3521$

114. Goldschneider I, Cone RE (2003) A central role for peripheral dendritic cells in the induction of acquired thymic tolerance. Trends Immunol 24:77-81. doi:10.1016/S1471-4906 (02)00038-8

115. Watanabe $\mathrm{N}$, Wang $\mathrm{YH}$, Lee HK, Ito T, Wang YH, Cao W, Liu YJ (2005) Hassall's corpuscles instruct dendritic cells to induce CD4+CD25+ regulatory $\mathrm{T}$ cells in human thymus. Nature 436:1181-1185. doi:10.1038/nature03886

116. Bonasio R, Scimone ML, Schaerli P, Grabie N, Lichtman AH, von Andrian UH (2006) Clonal deletion of thymocytes by circulating dendritic cells homing to the thymus. Nat Immunol 7:1092-1100. doi:10.1038/ni1385

117. Wu L, Shortman K (2005) Heterogeneity of thymic dendritic cells. Semin Immunol 17:304-312. doi:10.1016/j.smim.2005.05.001

118. Ladi E, Schwickert T, Chtanova T, Chen Y, Yin X, Le Borgne M, Aaron H, Herzmark P, Chan SW, Killeen N, Roysam B, Lipp M, Robey EA (2008) Thymocyte-dendritic cell interactions near sources of CCR7 ligands in the thymic cortex. FASEB J 22:661-669

119. Buhlmann JE, Elkin SK, Sharpe AH (2003) A role for the B7-1/ B7-2:CD28/CTLA-4 pathway during negative selection. J Immunol 170:5421-5428 